\section{Diarrheagenic Escherichia coli 0157 from Libya: recent perspectives and challenges}

Mohamed O. Ahmed,

Nariman F. Almshawt, Hiam R. EInageh

Department of Microbiology and

Parasitology, Faculty of Veterinary

Medicine, University of Tripoli, Libya

Diarrheal pathogens persist as a primary cause of high morbidity - and mortality gastrointestinal illnesses worldwide particularly in the developing world. ${ }^{1,2}$ Rotaviruses are a major cause of diarrheal illnesses, and a seasonal infection transmitted by the fecal-oral route. The increased incidence of rotavirus infection among human populations has been attributed to its wide-range presence in animals and ability to exchange genetic determinants between strains affecting animal and human hosts. ${ }^{3}$ Bacteria pathogens are also a leading cause of diarrhea, especially among children, and are reported to be responsible for significant morbidity, mortality, and economic losses, particularly in underdeveloped countries. ${ }^{2}$ In Libya, for instance, research studies of diarrheagenic agents have focused on bacteria and the pediatric population and different serogroups of Escherichia coli have been reported as a major cause of childhood diarrhoea. ${ }^{4-11}$

Entero-hemorrhagic E. coli [EHEC; also known by the acronyms Shiga toxinproducing E. coli (STEC), or verocytotoxin-producing E. coli (VTEC)] is one of the most common of the serogroups associated with gastroenteric illnesses and foodborne outbreaks. ${ }^{12}$ The Shiga toxins produced by this group of $E$. coli cause an array of complications in humans, ranging from uncomplicated diarrhea to life-threatening conditions such as hemorrhagic colitis, which can progress into hemolytic uremic syndrome (HUS) and severe acute renal failure. The STEC/VTEC encompass hundreds of serotypes capable of causing severe illnesses in humans, among which O157, O26, O111, O103 and O145 (the so-called top five) are the most frequently reported serogroups associated with human disease. ${ }^{13}$ The 0157 serogroup is the most commonly reported and has been the main cause of serious outbreaks, especially of foodborne infections. ${ }^{12}$ As such, E. coli O157 has emerged as a particular public health concern.

Ruminants, particularly cattle, are the natural reservoir of $E$. coli 0157 , which inhabit the intestinal tract of healthy animals. Infection of humans is typically acquired through contaminated food and drink (i.e. undercooked ground meat, raw milk, dairy products, raw vegetables, contaminated fruits) or through direct contact with animals. ${ }^{12,14}$ Generally speaking, publications describing research on the frequency and occurrence of important zoonotic bacterial organisms of public health concern from underdeveloped regions, such as Libya, are few and epidemiological information remains scarce ${ }^{5,14}$ However, researchers in Libya have begun reporting on the isolation of $E$. coli 0157 from a range of animals and animal products. Herein, we summarize the recent peer-reviewed articles on this topic and provide commentary to promote interest in this important public health concern and highlight the research opportunities (Table 1).

In Libya, $24-33 \%$ of pediatric diarrheal cases are caused by rotavirus rotavirus. ${ }^{4,15,16}$ In addition, a recent study uncovered an alarming trend in increasing incidence, with these cases estimated to represent up to $57 \% .{ }^{17}$ Bacterial pathogens are also reported to be a major cause of diarrhea in children and are responsible for an approximate $27 \%$ of the clinical samples examined. Several genogroups of $E$. coli have been characterized (i.e. EPEC, ETEC, EHEC, EIHC, EAEC) and found to express multidrug-resistant phenotypes. ${ }^{4,5,11}$ However, the epidemiology, phylogenetic relation and zoonotic features of the reported strains isolated from pediatric human cases, and at population level, are largely unknown

In Libya, the recently reported $E$. coli 0157 isolates from food-producing animals and most recently from animal products underscore the serious health concern facing this region (Table 1). Garbage et al., for instance, have reported the isolation of $E$. coli 0157 from raw milk and dairy products collected from different animals, with cow origin being predominant ( $7 / 11$ of total isolates). ${ }^{18}$ This particular study has reported raw goat milk as the most contaminated source (i.e. $2 / 7$ samples; $28.6 \%$ ). On the other hand, Abujnah et al. have reported a high isolation rate for $E$. coli 0157 from fresh white cheese samples $(35.6 \%$ of tested samples) collected from local factories around Tripoli; however, the animal origin of the samples was not clear. ${ }^{19}$

The consumption of raw or undercooked meat of bovine origin has been frequently reported to be the most common source of E. coli 0157 contamination and infection. A study of raw sausage specimens (locally known as almergaz) that had been collected from local markets in Tripoli isolated E. coli 0157 from $48 \%$, with $60 \%$
Correspondence: Mohamed O. Ahmed, Department of Microbiology and Parasitology, Faculty of Veterinary Medicine, University of Tripoli, P.O. Box 13662 Libya. Tel.: +21.8925400914

E-mail: a.mo@live.com; m.ahmed@uot.edu.ly

Key words: Diarrheal pathogens, Escherichia coli O157, public health, developing countries, Libya.

Contributions: MOA designed and wrote the article; NFA and HRE acquired references and data and participated in the writing up; all authors approved the final manuscript.

Conflict of interest: the authors declare no potential conflict of interest.

Received for publication: 22 April 2017

Accepted for publication: 24 April 2017.

This work is licensed under a Creative Commons Attribution NonCommercial 4.0 License (CC BY-NC 4.0).

(C) Copyright M.O. Ahmed et al., 2017

Licensee PAGEPress, Italy

Journal of Public Health in Africa 2017; 8:685 doi:10.4081/jphia.2017.685

genopositivity for stx genes among the isolated strains; however, the animal source of meat samples was not stated. ${ }^{20}$ Previously, studies have reported the isolation of this pathogen from burger meat specimens of beef and chicken origins. Considering the collective findings from these studies, the rates of isolation/contamination was found to range between $4-5 \%$ in cooked meat and from $20-27 \%$ in uncooked meat specimens of burgers (Table 1). ${ }^{21,22}$ Unfortunately, most of the previous studies have not determined the possible sources of these contaminant bacteria or the epidemiologic and phylogenetic relation among these strains and/or toward humans (either humans-incontact or the consumers).

Prevalence of E. coli 0157 in healthy dairy cows has been studied as well. In suburban areas of Tripoli, the reported rates range from $6-9 \% .{ }^{14,23}$ Shedding of E. coli 0157 from healthy cattle was reported to be significantly associated with signs of diarrhea and source of water-intake (identifying these parameters as risk factors of shedding). Surprisingly, age which is frequently associated with shedding of E. coli 0157, was not found to be a significant risk factor. Ultimately, healthy dairy cows have been posited as a natural reservoir of E. coli 0157 in Libya. A regional study from Egypt identified E. coli $\mathrm{O} 157$ isolates from marine life (seafood and animals from coastal water; $48 \%$ of tested samples). ${ }^{24}$ Thus, there is a 
Table 1. Summary of the prevalence and isolation frequencies of diarrheagenic Escherichia coli from humans, animals and animal products in Libya.

\begin{tabular}{|c|c|c|c|c|c|c|}
\hline Sample origin & $\begin{array}{l}\text { Origin and } \\
\text { source }\end{array}$ & N. tested samples & Total positivity, \% & $\begin{array}{c}\text { Identified } \\
\text { E.coli group and/or strains }\end{array}$ & $\begin{array}{l}\text { Identification } \\
\text { s method }\end{array}$ & Ref. \\
\hline Human Stool (Children) & $\begin{array}{l}\text { Diarrheic } \\
\text { Diarrheic } \\
\text { Diarrheic } \\
\text { Control } \\
\text { Diarrheic } \\
\text { Diarrheic } \\
\text { Control } \\
\text { Diarrheic } \\
\text { Control } \\
\text { Diarrheic } \\
\text { Control }\end{array}$ & $\begin{array}{l}239 \\
124 \\
157 \\
157 \\
243 \\
157 \\
157 \\
356 \\
100 \\
157 \\
157\end{array}$ & $\begin{array}{c}11.2 \% \\
0.7 \% \\
7.0 \% \\
4.4 \% \\
8.6 \% \\
0,11 \\
0,07 \\
0,04 \\
0 \\
8.9 \% \\
2.5 \%\end{array}$ & $\begin{array}{c}\text { EAEC, EPEC, EHEC, EIEC } \\
\text { O157:H7 } \\
\text { O157:H7 } \\
\text { EPEC, ETEC, EAEC } \\
\text { EPEC } \\
\text { EPEC } \\
\text { EPEC, EAEC }\end{array}$ & $\begin{array}{l}\text { PCR } \\
\text { Sera } \\
\text { Sera } \\
\text { PCR } \\
\text { Sera } \\
\text { Sera } \\
\text { PCR }\end{array}$ & $\begin{array}{l}4 \\
6 \\
7\end{array}$ \\
\hline Cattle & $\begin{array}{l}\text { Feaces } \\
\text { Feaces } \\
\text { Raw milk } \\
\text { Dairy products* } \\
\text { Burger }^{\circ}\end{array}$ & $\begin{array}{c}97 \\
200 \\
28 \\
49 \\
15^{\circ}\end{array}$ & $\begin{array}{c}6.2 \\
9 \\
3.5 \\
9.5 / 21.4 \\
5.4 / 27.1^{\circ}\end{array}$ & $\begin{array}{c}0157 \\
0157 \\
0157 \\
0157 \\
0157: \mathrm{H7}\end{array}$ & $\begin{array}{c}\text { Sera } \\
\text { Sera } \\
\text { 16srDNA-PCR } \\
\text { 16srDNA-PCR } \\
\text { Sera }\end{array}$ & $\begin{array}{l}14 \\
23 \\
18 \\
18 \\
21\end{array}$ \\
\hline Camel & Raw milk & 9 & 0 & 0157 & 16s rDNA-PCR & 18 \\
\hline Goat & Raw milk & 7 & 28.6 & $1057>$ & 16s rDNA-PCR & 18 \\
\hline Chicken & Burger $^{\circ}$ & $120^{\circ}$ & $4.7 / 20.3^{\circ}$ & 0157:H7 & Sera & 22 \\
\hline Unknown & $\begin{array}{l}\text { Raw sausages } \\
\text { Cheese }\end{array}$ & $\begin{array}{l}100 \\
87\end{array}$ & $\begin{array}{c}48 \\
35.6\end{array}$ & $\begin{array}{l}\text { 0157:H7 } \\
\text { O157:H7 }\end{array}$ & $\begin{array}{l}\text { Sera and PCR } \\
\text { Unspecified }\end{array}$ & $\begin{array}{l}20 \\
19\end{array}$ \\
\hline
\end{tabular}

ID, identification. *Dairy products [Include cheese $(\mathrm{n}=21 ; 9.5 \%)$ and fermented milk $(\mathrm{n}=28 ; 21.4 \%)$ ]; ${ }^{\circ}$ Burgers (sample size is presented in total and positive rates are in respect to cocked/raw products).

serious public health threat among important food resources of this region. Interestingly, recent reports have documented the possible association of outbreaks and infections with the new emergent $E$. coli serotype O104:H4 in Europe and travel history to North Africa. ${ }^{13}$ Environmental contaminants and waste materials of urban and suburban sources can harbor pathogenic and infectious agents and therefore pose a significant public health threat. The nondeveloped sanitary and health systems of underdeveloped regions can play a major role in the dissemination and emergence of infectious pathogens, such as E. coli 0157.

The collective peer-reviewed literature on this topic highlight the likely role of food-producing animals as a potential source and carrier of public health-threatening pathogens. However, the carriage status of E. coli 0157 in different food-producing animals and the related epidemiological information still require investigation. Also, information is absent on the most significant diarrheagenic $E$. coli that are frequently reported and associated with global human outbreaks. Documentation of E. coli 0157 isolates from animal products is necessary, so that appropriate prevention measures can be developed and applied to control risk in the food chain as well as in the environment. Thus, systematic epidemiological studies are required to determine an accurate estimation of the burden of $E$. coli O157 and other diarrheagenic strains, particularly in food-producing animals. This will require interactive collaboration between human and veterinary medicine professionals at the clinical, public health and research level.

\section{References}

1. Kosek M, Bern C, Guerrant RL. The global burden of diarrheal disease, as estimated from studies published between 1992 and 2000. Bull WHO 2003;81:197204.

2. Fletcher SM, Stark D, Ellis J. Prevalence of gastrointestinal pathogens in Sub-Saharan Africa: systematic review and meta-analysis. J Public Health Afr 2011;5:e30.

3. Khoury H, Ogilvie I, El Khoury AC, et al. Burden of rotavirus gastroenteritis in the Middle Eastern and North African pediatric population. BMC Infect Dis 2011;7:11:9.

4. Rahouma A, Klena JD, Krema Z, et al. Enteric pathogens associated with childhood diarrhea in Tripoli-Libya. Am J Trop Med Hyg 2011;84:886-1.

5. Ali MM, Mohamed ZK, Klena JD, et al. Molecular characterization of diarrheagenic Escherichia coli from Libya. Am J Trop Med Hyg 2012;86:866-1.

6. Shaban R, Abdulsalam B. Prevalence of Escherichia coli O157:H7 causing children diarrhea in Sirte, Libya. IDWeek Advance Science, Improving Care. 2013. p. 1293. Available from: https://idsa.confex.com/idsa/2013/webp rogram/Paper41774.html [cited 5 October 2013]

7. Ghenghesh KS, Ben-Taher S, Abeid S, Tawil A. Escherichia coli O157:H7 in children diarrhoea in Libya. Clin Microbiol Infect 1997;3:221.

8. Ghenghesh KS, Bara F, Bukris B, et al. Characterization of virulence factors of Aeromonas isolated from children with and without diarrhoea in Tripoli, Libya. J Diarrhoeal Dis Res 1999;17:75-80.

9. Ghenghesh KS, Abeid SS, Bara F, Bukris B. Etiology of childhood diarrhoea in Tripoli-Libya. Jamahiriya Med J 2001;1:23-9

10. Ghanim MA, Taher IAA, Ahmaida AI, Tobgi RS. Etiology of childhood diarrhea in Benghazi, Libya. Garyounis Med J 2003;20:22-4.

11. Dow MA, Toth I, Malik A, et al. Phenotypic and genetic characterization of enteropathogenic Escherichia coli (EPEC) and entero-aggregative E. coli (EAEC) from diarrhoeal and non-diarrhoeal children in Libya. Comp Immunol Microbiol Infect Dis 2006;29:100-3.

12. Islam MZ, Musekiwa A, Islam K, et al. Regional Variation in the prevalence of E. coli O157 in cattle: a meta-analysis and meta-regression. PLoS One 2014;9:e93299.

13. De RK, Vincken S, Garabedian L, et al. Enteroaggregative Shiga toxin-producing Escherichia coli of serotype 
O104:H4 in Belgium and Luxembourg. New Microbes New Infect 2014;2:1383.

14. Ahmed MO, Abouzeed YM. Enterohaemorrhagic Escherichia coli O157: a survey of dairy cattle in Tripoli, Libya. Libyan J Med 2014;9:24409.

15. Abugalia M, Cuevas L, Kirby A, et al. Clinical features and molecular epidemiology of rotavirus and norovirus infections in Libyan children. J Med Virol 2011;83:1849-6.

16. Kalaf RN, Elahmer OR, Zorgani AA, Ghenghesh KS. Rotavirus in children with diarrhea in Tripoli, Libya. Libyan J Med 2011;18:6.

17. Alkoshi S, Ernst K, Maimaiti N, Dahlui M. Rota viral infection: a significant disease burden to Libya. Iran J Public
Health 2014;43:1356-3.

18. Garbaj AM, Awad EM, Azwai SM, et al. Enterohemorrhagic Escherichia coli O157 in milk and dairy products from Libya: isolation and molecular identification by partial sequencing of $16 \mathrm{~S}$ rDNA. Vet World 2016;9:1184-9.

19. Abujnah YS, El Magdoli LS, Gnan SO, et al. Bacteriological quality and incidence of some pathogenic bacteria in fresh white cheese sold in Tripoli, Libya. J Microb Biochem Technol 2016;8:307-1

20. Ben Hamza IM. Detection of stx gene of E.coli $0157: \mathrm{H} 7$ in sausages by using polymerase chain reaction (PCR) in Tripoli. The Libyan Academy of Graduate Studies 2012. Ref no. 4556.

21. Elshrek YM, Madi NS, El-Bakoush E,
El-Tawil A. Microbiological studies of spiced beef burgers in Tripoli city, Libyan Arab Jamahiriya. East Mediterr Health J 2008;14:172-8.

22. El Shrek YM, Ali MR. Microbiological study of spiced chicken burgers in Tripoli City, Libya. East Mediterr Health J 2012;18:653-2.

23. Helmi HA. The prevalence of verocytotoxin-producing Escherichia coli 0157 (VTEC) in dairy cattle in Tripoli area. Thesis dissertation. Faculty of veterinary medicine 2013.

24. El-shenawy MA, EL-shenawy M. Enterohaemorrhagic Escherichia coli O157 in coastal environment of Alexandria, Egypt. Microb Ecol Health Dis 2005;17:103-6. 